\title{
PENGARUH PENGALAMAN, INDEPENDENSI, GENDER AUDITOR TERHADAP KUALITAS AUDIT
}

\section{Irma Suryani, Asep Efendi dan Fitriana}

Universitas Sangga Buana YPKP Bandung Jawa Barat, Indonesia

Email: Irmasuryani2603@gmail.com, asepeffendiusb@gmail.com dan fitrianadachlan64@gmail.com

\section{Abstract}

This research was conducted because of the number of cases of audit failure that mghasilka poor audit quality, alleged experience, independesi, gender auditor brpgaruh to the quality of audit supported by the inconsistencies of the results of previous research. This research was conducted to see the independence, experience, gender and quality of audits in Central Jakarta Public Accountants and to see the influence of independence, experience, gender on audit quality. The population in the study was a permanent auditor working atkap Central Jakarta registered in the IAPI 2019 directorate. The study population was 265 auditors. Determination of sample size using the Slovin formula. The sampling technique used was probability sampling and the number of samples in this study was 72 fixed auditors. The research method used is descriptive and verifikative method. Data analysis method uses multiple linear regression analysis using SPSS 20. The results of the study prove that: (1) auditor experience in KAP Central Jakarta belongs to the high category (2) independence of auditors in KAP Central Jakarta including the very high category (3) gender auditors in KAP Central Jakarta dominated by men, the results showed that female auditors are better at auditing. (4) The quality of auditors at KAP Central Jakarta is of a high category, (5) the auditor's experience has a negative and insignificant effect on the partial audit quality, (6) Independence has a positive and significant effect on the quality of audits, (7) gender has a negative and significant effect on the quality of audits partially, (8) experience, independence, gender auditors influence the quality of audits simultaneously.

Keywords: experience; independence; gender; audit quality

\begin{abstract}
Abstrak
Penelitian dilakukan karena banyaknya kasus kegagalan audit yang menghasilkan kualitas audit yag buruk, diduga pengalaman, independesi, gender auditor terhadap kualitas audit didukung dengan adanya inkonsistensi hasil penelitian terdahulu. Penelitian ini dilakukan untuk melihat independensi, pengalaman, gender dan kualitas audit di KAP Jakarta Pusat serta pengaruhnya terhadap kualitas audit. Populasi pada penelitian adalah auditor tetap yang bekerja di Kantor Akuntan Publik (KAP) Jakarta Pusat yang terdaftar di direktorat IAPI 2019. populasi penelitian adalah 265 auditor. Penentuan sampel menggunakan rumus Slovin. Teknik pengambilan sampel menggunakan probability sampling dengan jumlah sampel adalah 72 auditor tetap. Metode penelitian menggunakan metode deskriptif
\end{abstract}


dan verifikatif. Metode analisis data menggunakan analisis regresi linier berganda dengan menggunakan SPSS 20. Hasil penelitian membuktikan bahwa: (1) pengalaman auditor di KAP Jakarta Pusat termasuk kategori tinggi (2) independensi auditor di KAP Jakarta Pusat termasuk kategori sangat tinggi (3) gender auditor di KAP Jakarta Pusat di dominasi oleh laki-laki, hasil penelitian menunjukan auditor wanita lebih baik dalam mengaudit. (4) kualitas auditor di KAP Jakarta Pusat termasuk kategori tinggi, (5) pengalaman auditor berpengaruh negatif dan tidak signifikan terhadap kualitas audit secara parsial, (6) Independensi berpengaruh positif dan signifikan terhadap kualitas audit secara parsial, (7) gender berpengaruh negatif dan signifikan terhadap kualitas audit secara parsial, (8) pengalaman, independensi, gender auditor berpengaruh terhadap kualitas audit secara simultan.

Kata kunci: pengalaman; independensi; gender; kualitas audit

\section{Pendahuluan}

Memberikan kepastian bahwa laporan keuangan yang diterbitkan tidak mengandung informasi yang menyesatkan pemakainya adalah peran dari seorang akuntan publik. Tujuannya untuk kepentingan umum adalah penyajian informasi mengenai posisi keuangan (financial position), kinerja keuangan (financial performance), dan arus kas (cash flow) dari entitas yang sangat berguna untuk membuat keputusan ekonomis bagi para penggunanya seperti pemegang saham, pemerintah,dan kreditor.

Peran akuntan publik dirasa sangat penting oleh karena itu Ikatan Akuntan Indonesia (IAI) mengeluarkan Standar Profesional Akuntan publik dan Kode Etik untuk menjaga kredibilitas dari akuntan publik agar kepercayaan masyarakat tidak berkurang. Pelanggaran yang dilakukan PT. Sunprime Nusantara Pembiayaan (SNP Finance) akhirakhir ini yang melibatkan akuntan publik (AP) Marlinna, AP Merliyana Syamsul dan Kantor Akuntan Publik (KAP) Satrio, Bing, Eny dan Rekan, yang merupakan salah satu KAP di bawah Delloite Indonesia yang mana telah memberikan opini yang tidak mencerminkan kondisi perusahaan yang sebenarnya (Burhanudin \& Rahmawati, 2017).

Kasus tersebut menambah deretan kasus kegagalan audit dan berakibat kurangnnya rasa percaya masyarakat terhadap profesi akuntan publik, karena kasus tersebut melibatkan profesi akuntan publik yang seharusnya sebagai pihak ketiga yang independen, yang memberikan jaminan atas relevansi dan keandalan sebuah laporan keuangan. Adanya kasus tersebut timbul pertanyaan bagaimana keahlian yang dimilki auditor sehigga dapat melakuka kelalaian tersebut atau mungkin ada intervensi pihak tertentu sehingga mempengaruhi independensinya.

Menurut (Segah, 2018) keahlian sebagai seseorang yang memiliki pengetahuan dan keterampilan prosedural yang luas yang ditunjukan dalam pengalaman audit. (Sarca \& Rasmini, 2019) menyatakan pengalaman kerja secara langsung maupun tidak langsung akan menambah keahlian auditor dalam menjalankan tugasnya. (Tandiontong, 2013) menyatakan auditor yang berpengalaman diasumsikan dapat memberikan kualitas audit yang lebih baik dibandingkan dengan auditor yang belum berpengalaman. 
Independensi merupakan sikap yang tidak mudah dipengaruhi, dan tidak memihak pada siapapun. (Momon, Rachbini, \& Amilin, 2018) menyatakan tingkat independensi merupakan faktor yang menentukan kualitas audit, hal ini dipahami karena jika auditor benar-benar independen maka tidak akan terpengaruh dengan auditee. Namun jika tidak memiliki independensi terutama jika mendapat tekana-tekanan dari auditee, maka kualitas yang dihasilkannya juga tidak akan maksimal.

Hasil penelitian mengenai pengaruh pengalaman auditor terhadap kualitas audit pernah dilakukan oleh (Turgarini, 2018), (Saputra, Adha, Ariyanti, \& Gunawan, 2019), (Vangara, Kumar, Gopichand, \& Puri, 2019), (Agustina et al., 2019) membuktikan bahwa pengalaman berpengaruh terhadap kualitas audit. Berbeda dengan hasil penelitian (Septiana, Munthe, Fatimah, \& Latifah, 2019), (Yohana Ariska Sihombing \& Triyanto, 2019) yang membuktikan bahwa pengalaman tidak berpengaruh terhadap kualitas audit.

Hasil penelitian mengenai pengaruh independensi auditor terhadap kualitas audit yang pernah dilakukan oleh (Oktaviani, 2016), (Siahaan \& Simanjuntak, 2019), (Palupi, Suratno, \& Amilin, 2018), (Gunur, Makur, \& Ramda, 2018), (Vangara et al., 2019), (Yuniar, 2019), (Laksita \& Sukirno, 2019), membuktikan bahwa independensi berpengaruh positif dan signifikan terhadap kualitas audit. Berbeda dengan hasil penelitian (Mulyani \& Munthe, 2018), Suharti \& Apriyanti (2019) yang membuktikan bahwa independensi tidak berpengaruh terhadap kualitas audit.

Rahayu \& Suryanawa (2019) berpendapat gender tidak hanya sebagai pembeda antara laki-laki dan perempuan secara biologis tetapi gender lebih dilihat dari segi sosial dan cara menerima, menghadapi dan memperoses informasi yang diterima untuk melaksanakan pekerjaan dan membuat keputusan. Sama halnya dengan pengalaman dan independensi, hasil penelitian mengenai gender terhadap kualitas audit yang telah dilakukan menunjukan hasil yang tidak konsisten. Hasil penelitian yang pernah dilakukan oleh (Saputra et al., 2019), (Huda, Hudori, Fahlevi, Mazaya, \& Sugiarti, 2017) membuktikan bahwa gender berpengaruh positif terhadap kualitas audit. Berbeda dengan hasil penelitian yang dilakukan oleh (Rahayu \& Suryanawa, 2019) yang membuktikan bahwa gender berpengaruh negatif dan signifikan terhadap kualitas audit. Hal tersebut juga berbeda dengan hasil penelitian yang dilakukan oleh (Ariningsih \& Mertha, 2017) yang membuktikan gender tidak berpengaruh terhadap kuallitas audit.

Hal tersebut di atas menjadi pertimbangan penulis mengambil penelitian tentang kualitas audit dan Adanya perbedaan hasil penelitian terdahulu mengenai faktor-faktor yang berpengaruh terhadap kualitas audit.

Rumusan masalah pada penelitian ini adalah (1)Bagaimana pengalaman, independensi, gender dan kualitas audit pada KAP di Jakarta Pusat?, (2) Bagaimana pengaruh pengalaman terhadap kualitas audit pada KAP di Jakarta Pusat?, (3) Bagaimana pengaruh independensi terhadap kualitas audit pada KAP di Jakarta Pusat?, (4) Bagaimana pengaruh gender terhadap kualitas audit pada KAP di Jakarta Pusat?, (5) Bagaimana pengaruh pengalaman, independensi dan gender auditor secara simultan terhadap kualitas audit pada KAP di Jakarta Pusat? 


\section{Metode Penelitian}

Metode Penelitian yang digunakan dalam penelitian ini adalah metode deskriptif dan verifikatif.Metode deskriptif digunaka untuk menjawab rumusan masalah nomor 1 sedangkan metode verifikatif digunakan untuk menjawab rumusan masalah nomor 2 sampai 5. Populasi dalam penelitian ini adalah auditor tetap di Kantor Akuntan Publik Jakarta pusat. Menurut IAPI KAP yang terdaftar di Jakarta Pusat sebanyak 56 KAP dengan 256 auditor tetap. Penentuan ukuran sampel dalam penelitian ini dilakukan dengan rumus Slovin sehingga didapat jumlah sampel sebanyak 72 auditor.

Penelitian ini menggunakan 4 variabel yang terdiri dari tiga variabel bebas yaitu pengalaman (X1), independensi (X2) dan gender auditor (X3) dan kualitas audit (Y) sebagai variabel terikat. Keempat variabel tersebut dianalisis dengan menggunakan analisis regresi linier berganda dibantu dengan SPSS 20.

\section{Hasil dan Pembahasan}

\section{A. Hasil Penelitian}

\section{Analisis Deskriptif}

Metode deskriptif menurut (Nazir, 2011) merupakan metode penelitian untuk memperoleh deskripsi tentang ciri-ciri variabel, seringkali disebut metode survey. Dalam penelitian ini Analisis Deskriptif digunakan untuk mengetahui gambaran variabel yang diteliti yaitu pengalaman, independensi, gender, dan kualitas audit dengan menggunakan SPSS 20.

Tabel 1

Hasil uji statistik deskriptif

\begin{tabular}{cccccc}
\hline Variabel & N & Minimum & Maximum & Mean & Std. Deviation \\
\hline Pengalaman & 72 & 28 & 41 & 36,19 & 2,710 \\
\hline Independensi & 72 & 29 & 48 & 40,21 & 5,007 \\
\hline Kualitas Audit & 72 & 18 & 28 & 24,17 & 2,227 \\
\hline \multicolumn{5}{c}{ Sumber: Hasil olah data SPSS }
\end{tabular}

\section{Hasil Uji kualitas data}

\section{a. Hasil uji Validitas}

Menurut (Ambarwati, Yuniarta, AK, \& Sinarwati, 2015). Dilakukannya uji validitas yaitu untuk mengetahui apakah setiap item di dalam kuesioner mampu mengungkapkan dengan pasti mengenai apa yang diteliti Uji Validitas dalam penelitian ini dilakukan dengan menggunakan program Statistical Package for Social Science (SPSS) 20 dengan ujimenggunakan korelasi Bivariate Pearson (produk momen pearson). Koefesien korelasi pearson dengan $r$ tabel untuk df (degre of freedom), $\mathrm{df}=\mathrm{n}-\mathrm{k}$, dimana $\mathrm{n}$ merupakan jumlah responden dan $\mathrm{k}$ merupakan jumlah variabel yang digunakan. Jadi:df $=\mathrm{n}-\mathrm{k}$, df $=72-4$, df $=68$ dengan $\alpha=0,1$ di dapat nilai $r$ tabel yaitu 0,220 .

Setelah dilakukan pengolahan data terlihat bahwa dari 8 item pada variabel pengalaman, ada 1 item yang dinyatakan tidak valid yaitu item nomor 8 karena $r$ 
hitung dari item 8 adalah 0,175 sedangkan $r$ tabel nya 0,220. Berdasarkan kriteria pengambilan keputusan jika $r$ hitung $<r$ tabel maka dinyatakan tidak valid.

Hasil uji validitas pada variabel Independensi yang memiliki 14 item soal, ada 3 butir pernyataan dinyatakan tidak valid yaitu pada item 9 dengan $r$ hitung $-0,105$, item 16 dengan nilai $\mathrm{r}$ hitung 0,174 dan item 21 dengan nilai $\mathrm{r}$ hitung 0,079. Ketiganya memiliki $r$ hitung lebih kecil dari $r$ tabel. Sehingga jumlah Pernyataan yang valid adalah 11 Item soal. hasil uji validitas seluruh item memiliki $r$ hitung $>r$ tabel, maka dapat disimpulkan semua item pada variabel Kualitas Audit dinyatakan valid.

\section{b. Hasil Uji Reliabilitas}

Pengujian reliabilitas dipergunakan dalam peneitian ini adalah untuk memastikan apakah kuesioner penelitian yang digunakan untuk mengumpulkan data variabel penelitian reliabel atau tidak Uji reliabilitas dlam plitia ii dilakukan menggunakan Cronbach's Alpha SPSS 20.

Tabel 2

Hasil uji reliabilitas

\begin{tabular}{cc}
\hline Cronbach's Alpha & $\mathrm{N}$ of Items \\
\hline 0,665 & 22 \\
\hline Sumber: Hasil olah data SPSS
\end{tabular}

Diketahui $\mathrm{N}$ of item merupakan jumlah butir pernyataan (angket) adalah ada 22 dengan nilai chronbach Alpha sebesar 0,665 maka dapat dikatakan bahwa 22 item pertanyaan angket tersebut reliabel karena nilai Cronbach alpha 0,665 $>0,6$.

\section{Hasil uji asumsi klasik}

\section{a. Hasil uji normalitas}

Uji normalitas digunakan untuk menguji apakah pada model regresi, varibel penganggu atau residual berdistribusi normal atau tidak. Uji normalitas dalam penelitian ini menggunakan aplikasi IBM SPSS 20 uji statistitik kolmogrorovsimirnov (K-S) ditunjukkan pada tabel 3.

Tabel 3

Hasil Uji Normalitas One-Sample Kolmogorov-Smirnov Test

\begin{tabular}{llr}
\hline & & Unstandardized Residual \\
\hline $\mathrm{N}$ & & 72 \\
\hline \multirow{2}{*}{ Normal Parameters ${ }^{\mathrm{a}, \mathrm{b}}$} & Mean & $0 \mathrm{E}-7$ \\
\cline { 2 - 3 } Most Extreme & Std. Deviation & 2,09818736 \\
\cline { 2 - 3 } Differences & Absolute & 0,061 \\
\cline { 2 - 3 } & Positive & 0,059 \\
\cline { 2 - 3 } & Negative & $-0,061$ \\
\hline Kolmogorov-Smirnov Z & & 0,520 \\
\hline Asymp. Sig. (2-tailed) & & 0,950 \\
$\begin{array}{l}\text { a. Test distribution is Normal. } \\
\text { b. Calculated from data. }\end{array}$ &
\end{tabular}

Sumber: Hasil olah data SPSS 
Berdasarkan output SPSS di atas diketahui bahwa nilai signifikansi asymp. Sig (2 tiled) sebesar 0,950 lebih besar dari 0,1. Maka sesuai dengan dasar pengambilan keputusan dalam uji normalitas kolmogorov-sirnov di atas, dapat dikatakan bahwa data terdistribusi normal.

\section{b. Hasil Uji multikolinearitas}

Uji multikolinieritas bertujuan untuk menguji apakah dalam model regresi ditemukan adanya korelasi antar variabel bebas (independen)

Tabel 4

hasil uji multikolinearitas

Coefficients ${ }^{\mathrm{a}}$

\begin{tabular}{|c|c|c|c|c|c|c|c|c|}
\hline \multirow{2}{*}{\multicolumn{2}{|c|}{ Model }} & \multicolumn{2}{|c|}{$\begin{array}{c}\text { Unstandardized } \\
\text { Coefficients }\end{array}$} & \multirow{2}{*}{$\begin{array}{c}\text { Standardized } \\
\text { Coefficients } \\
\text { Beta }\end{array}$} & & \multirow{2}{*}{ Sig. } & \multicolumn{2}{|c|}{$\begin{array}{l}\text { Collinearity } \\
\text { Statistics }\end{array}$} \\
\hline & & B & $\begin{array}{l}\text { Std. } \\
\text { Error }\end{array}$ & & & & Tolerance & VIF \\
\hline & (Cons & 23,098 & 4,259 & & 5,423 & 0,000 & & \\
\hline & Gender & $-1,142$ & 0,549 & $-0,243$ & $-2,081$ & 0,041 & 0,954 & 1,048 \\
\hline & Pengalaman & $-0,076$ & 0,095 & $-0,092$ & $-0,798$ & 0,428 & 0,980 & 1,021 \\
\hline & Independensi & 0,114 & 0,053 & 0,256 & 2,163 & 0,034 & 0,936 & 1,069 \\
\hline
\end{tabular}

a. Dependent Variable: Kualitas

Sumber: Hasil olah data SPSS

Berdasarkan output SPSS "coefficients" pada bagian "collinarity statistics" diketahui nilai tolerance untuk variabel Pengalaman (x1) 0,980, variabel indpendensi (x2) 0,936 dan variabel gender (x3) 0,954 nilai ketiganya lebih besar dari 0,1. Sementara, nilai VIF untuk variabel Pengalaman 1,021, variabel indpendensi 1,069 dan untuk variabel gender 1,048 nilai dari ketiganya <10,00. Maka mengacu pada dasar pengambilan keputusan dalam uji multikolinearitas dapat disimpulkan bahwa tidak terjadi gejala multikolinearitas dalam model regresi.

\section{c. Hasil Uji Heteroskedastisitas}

Uji heteroskedastisitas bertujuan untuk menguji apakah dalam model regresi terjadi ketidaksamaan variance dari residual satu pengamatan ke pengamatan yan lain Uji heteroskedastisitas menggunakan bantuan aplikasi IBM SPSS 20 dengan cara melakukan Uji glejseer.

Tabel 5

hasil uji heteroskedasitias

\begin{tabular}{|c|c|c|c|c|c|c|c|}
\hline \multirow[t]{2}{*}{ Model } & \multicolumn{2}{|c|}{$\begin{array}{l}\text { Unstandardized } \\
\text { Coefficients }\end{array}$} & \multirow{2}{*}{$\begin{array}{c}\begin{array}{c}\text { Standardized } \\
\text { Coefficients }\end{array} \\
\text { Beta }\end{array}$} & \multirow[t]{2}{*}{$\mathrm{t}$} & \multirow[t]{2}{*}{ Sig. } & \multicolumn{2}{|c|}{$\begin{array}{l}\text { Collinearity } \\
\text { Statistics }\end{array}$} \\
\hline & $\mathrm{B}$ & $\begin{array}{l}\text { Std. } \\
\text { Error }\end{array}$ & & & & Tolerance & VIF \\
\hline (Constant) & $-1,030$ & 2,433 & & $-0,423$ & 0,673 & & \\
\hline Gender & 0,112 & 0,313 & 0,044 & 0,358 & 0,721 & 0,954 & 1,048 \\
\hline Pengalaman & 0,024 & 0,054 & 0,054 & 0,447 & 0,657 & 0,980 & 1,021 \\
\hline Independensi & 0,044 & 0,030 & 0,181 & 1,469 & 0,146 & 0,936 & 1,069 \\
\hline
\end{tabular}

a. Dependent Variable: Abs_RES

Sumber: Hasil olah data SPSS 
Berdasarkan output di atas diketahui nilai signifikansi (sig) untuk variabel pengalaman adalah 0,657 nilai signifikansi variabel independensi 0,146 dan untuk nilai signifikansi variabel gender 0,721. Karna nilai signifikansi ketiga variabel di atas > dari 0,1 maka dapat dikatakan tidak terjadi heteroskedastisitas.

\section{Hasil Uji Statistik}

\section{a. Uji Kofesien Determinasi}

\section{Tabel 6}

Hasil uji koefisien determinasi

\begin{tabular}{lrrrr}
\hline Model & R & R Square & $\begin{array}{c}\text { Adjusted R } \\
\text { Square }\end{array}$ & $\begin{array}{c}\text { Std. Error of } \\
\text { the Estimate }\end{array}$ \\
\hline 1 & 0,335 & 0,112 & 0,073 & 2,144
\end{tabular}

a. Predictors: (Constant), IND, PENG, GEN Sumber: Hasil olah data SPSS

Berdasarkan hasil pengujian di atas diperoleh angka $R$ Square sebesar 0,112 atau $11 \%$, hal ini menunjukan bahwa $11 \%$ kualitas audit dipengaruhi oleh variabel pengalaman, independensi, dan gender. Sisanya yaitu sebesar $89 \%$ (100\% -11\%) dipengaruhi oleh faktor lainnya diluar ketiga variabel yang diamati.

\section{b. Hasil Uji hipotesis Simultan (uji F)}

Tabel 7

Hasil Uji Simultan( uji F)

\begin{tabular}{|c|c|c|c|c|c|}
\hline Model & $\begin{array}{l}\text { Sum of } \\
\text { Squares }\end{array}$ & & Mean Square & $\mathrm{F}$ & Sig. \\
\hline Regression & 39,430 & 3 & 13,143 & 2,859 &, $043^{\mathrm{b}}$ \\
\hline 1 Residual & 312,570 & 68 & 4,597 & & \\
\hline Total & 352,000 & 71 & & & \\
\hline
\end{tabular}

a. Dependent Variable: Kualitas

b. Predictors: (Constant), IND, PENG, GEN

Sumber: Hasil olah data SPSS

Berdasarkan hasil pengujian hipotesis (uji F) pada tabel 7. di atas didapat nilai signifikansi regresi secara simultan sebesar 0,043, nilai ini lebih kecil dari significance $0,1(10 \%)$, yaitu $0,043<0,1$. Selain itu dapat dilihat juga dari hasil perbandingan antara $F_{\text {hitung }}$ dan $F_{\text {tabel }}$ yang menunjukan nilai Fhitung sebesar 2,859 sedangkan $F_{\text {tabel }}$ sebesar 2,166. Dari hasil tersebut terlihat bahwa $F_{\text {hitung }}>$ $\mathrm{F}_{\text {tabel }}$ yaitu 2,859>2,166, maka dapat disimpulkan bahwa secara simultan, maka Ho ditolak artinya seacara bersama-sama atau secara simultan variabel Pengalaman, independensi dan gender secara signifikan berpengaruh terhadap variabel dependen yaitu variabel kualitas audit. 


\section{c. Hasil Uji Parsial (uji t)}

Tabel 8

Hasil Uji Parsial(uji t)

\begin{tabular}{|c|c|c|c|c|c|c|}
\hline \multirow{2}{*}{\multicolumn{2}{|c|}{ Model }} & \multicolumn{2}{|c|}{$\begin{array}{l}\text { Unstandardized } \\
\text { Coefficients }\end{array}$} & \multirow{2}{*}{$\begin{array}{c}\text { Standardized } \\
\text { Coefficients } \\
\text { Beta } \\
\end{array}$} & \multirow[t]{2}{*}{$\mathrm{t}$} & \multirow[t]{2}{*}{ Sig. } \\
\hline & & B & Std. Error & & & \\
\hline \multirow{4}{*}{1} & (Constant) & 23,098 & 4,259 & & 5,423 & 0,000 \\
\hline & GEN & $-1,142$ & 0,549 & $-0,243$ & $-2,081$ & 0,041 \\
\hline & PENG & $-0,076$ & 0,095 & $-0,092$ & $-0,798$ & 0,428 \\
\hline & IND & 0,114 & 0,053 & 0,256 & 2,163 & 0,034 \\
\hline
\end{tabular}

a. Dependent Variable: KUALITAS

Sumber: Hasil olah data SPSS

Berdasarkan tabel 8 hasil pengujian secara parsial dapat dilihat utuk variabl pengalaman sebesar 0,428>0,1 (taraf nyata signifikansi penelitian). Selain itu juga dapat dilihat hasil perbandingan antara $t_{\text {hitung }}$ dan $t_{\text {tabel }}$ yang menunjukan nilai thitung sebesar $-0,798$, sedangkan $t_{\text {tabel }}$ sebesar 1,667. Dari hasil tersebut terlihat bahwa thitung $<t_{\text {tabel }}$ yaitu $0798<1,667$. Dengan demikian maka Ho diterima dan H1 ditolak, sehingga dapat disimpulkan bahwa secara parsial pengalaman tidak berpengaruh secara signifikan terhadap kualitas audit. Variabel independensi sebesar $0,034<0,1$ (taraf nyata signifikansi penelitian). Perbandingan antara $t_{\text {hitung }}$ dan $t_{\text {tabel }}$ juga menunjukan nilai $t_{\text {hitung }}$ sebesar 2,163, sedangkan $t_{\text {tabel }}$ sebesar 1,667 . Hasil tersebut menunjukan bahwa thitung $>t_{\text {tabel }}$ yaitu 2,163> 1,667, jadi dapat disimpulkan bahwa Ho ditolak dan H1 diterima artinya secara parsial variabel independensi auditor berpengaruh positif dan signifikan terhadap variabel kualitas audit. Variabl gender sebesar 0,041<0,1 (taraf nyata signifikansi penelitian). Perbandingan antara $t_{\text {hitung }}$ dan $t_{\text {tabel }}$ juga menunjukan nilai thitung sebesar $-2,002$, sedangkan $t_{\text {tabel }}$ sebesar 1,667. Dari hasil tersebut terlihat bahwa $t_{\text {hitung }}>t_{\text {tabel }}$ yaitu $-2,002>1,667$, maka dapat disimpulkan bahwa H1diterima dan Ho ditolak, artinya secara parsial variabel gender berpengaruh negatif dan signifikan terhadap variabel kualitas audit.

Dari tabel di atas pun dapat diperoleh persamaan regresi sebagai berikut:

$$
\mathrm{Y}=23,098-0,076 \mathrm{X} 1+0,114 \mathrm{X} 2-1,142 \mathrm{X} 3+\mathrm{e}
$$

Nilai konstanta sebesar 23,098 memiliki arti apabila variabel independen yaitu variabel pengalaman(X1), independensi(X2) dan gender (X3) sama dengan (0) ,maka variabel dependen yaitu kualitas audit sebesar 23,098 dengan catatan variabel lain dianggap konstan. 


\section{B. Pembahasan}

\section{Analisis Deskriptif}

Berdasarkan analisis deskriptif untuk variabel pengalaman, dapat ditarik kesimpulan bahwa kecendrungan frekuensi variabel pengalaman masuk kategori tinggi. kecendrungan frekuensi variabel independensi masuk kategori sangat tinggi dan kecendrungan frekuensi variabel kualitas audit masuk kategori kategori tinggi

\section{Analisis Verifikatif}

\section{a. Pengaruh Pengalaman Auditor terhadap Kualitas Audit pada KAP Jakarta Pusat}

Hipotesis pertama memprediksi bahwa pengalaman berpengaruh terhadap kualitas audit, yang merupakan jawaban sementara untuk rumusan masalah nomor 2 (dua). Berdasarkan hasil uji t (parsial) pada model regresi, diperoleh nilai signifikansi variabel pengalaman sebesar 0,428>0,1 (taraf nyata signifikansi penelitian). Hasil perbandingan antara thitung dan tabel juga menunjukan nillai t hitung sebesar -0,798, sedangkan tabel sebesar 1,667. Hasil tersebut menunjukan thitung < ttabel yaitu $-0798<1,667$, sehingga dapat disimpulkan bahwa secara parsial pengalaman tidak berpengaruh secara signifikan terhadap kualitas audit.Dengan demikian hipotesis pertama ditolak.

Besarnya pengaruh variabel pengalaman terhadap kualitas audit secara parsial dapat dilihat dari hasil perhitungan determinasi parsial. Berdasarkan determinasi parsial besarnya pengaruh pengalaman terhadap kualitas sangat kecil yaitu sebesar $-1,1 \%$ terhadap kualitas audit. Sehingga dapat dikatakan tidak terdapat pengaruh pengalaman terhadap kualitas audit. Berdasarkkan hasil analisis deskriptif, bahwa pengalaman kerja auditor KAP Jakarta Pusat masuk kategori tinggi. Masa kerja yang dimiliki responden di KAP Jakarta pusat, mayoritas memiliki masa kerja lebih dari 2 tahun,dapat dikatakan auditor diKAP Jakarta Pusat sudah berpengalaman.

Diasumsikan semakin berpengalaman seorang auditor, kualitas audit yang dihasilkan semakin baik. Namun hasil penelitian yang telah dilakukan di KAP Jakarta Pusat asumsi tersebut tidak terbukti.Pengalaman tidak berpengaruh signifikan terhadap kualitas audit. Hal ini menunjukan kemungkinan besar kualitas audit di KAP Jakarta Pusat tidak hanya ditentukan oleh pengalaman, namun ada faktor lain yang harus auditor miliki untuk menghasilkan kualitas audit yang baik. Selain tetap mengikuti prosedur dan standar audit yang telah ditetapkan, juga harus memiliki sikap skeptisme profesional sebagai sikap yang tidak mudah percaya akan bukti audit yang disajikan manajemen, sikap yang selalu mempertanyakan dan mengevaluasi bukti audit secara kritis.

Auditor yang berpengalaman dibidang audit, semakin mengerti bagaimna menghadapi pemeriksaan, mengambil pertimbangan dalam membuat 
keputusan audit dan dapat menyelesaikan pekerjaan dengan cepat dan dalam waktu yang tepat, artinya tepat sesuai dengan waktu yang direncanakan. Hasil penelitian ini sejalan dengan penelitian (Mulyani \& Munthe, 2018) juga (Ade Andrianto Sihombing, 2019) yang membuktikan bahwa pengalaman tidak berpengaruh terhadap kualitas audit.

b. Pengaruh Independensi Auditor Terhadap Kualitas Pada KAP Jakarta Pusat

Berdasarkan pengujian hipotesis kedua independensi berpengaruh terhadap kualitas audit. Hipotesis kedua ini merupakan jawaban sementara untuk rumusan masalah nomor 3(tiga). Berdasarkan hasil uji $\mathrm{t}$ (parsial) diperoleh nilai signifikansi variabel independensi sebesar $0,034<0,1$ (taraf nyata signifikansi penelitian). Hasil dari perbandingan antara thitung dan ttabel juga menunjukan nilai thitung sebesar 2,163, sedangkan ttabel sebesar 1,667. Hasil tersebut terlihat bahwa thitung > ttabel yaitu 2,163>1,667 .Hasil penelitian menunjukan terdapat pengaruh positif antara independensi terhadap kualitas. Maka dapat disimpulkan bahwa hipotesis kedua diterima.

Besarnya pengaruh variabel independensi terhadap kualitas audit secara parsial dapat dilihat dari hasil perhitungan determinasi parsial.Berdasarkan determinasi parsial besarnya pengaruh independensi terhadap kualitas audit yaitu sebesar 5,5\%. Sehingga dapat dikatakan terdapat pengaruh pengalaman terhadap kualitas audit namun pengaruhnya kecil.

Berdasarkkan hasil analisis deskriptif, bahwa independensi auditor KAP Jakarta Pusat masuk kategori sangat tinggi. Hal ini menunjukan auditor di KAP Jakarta pusat sudah bebas dari pengaruh ,seperti tekanaan darik lien,

Nilai dari kualitas audit adalah independensi, Independensi berarti sikap mental yang bebas dari pengaruh, tidak dikendalikan dan tidak tergantung pihak lain dalam artian klien. Semakin independen auditor kualitas yang dihasilkan akan semakin baik.Sehingga ditekankan perlunya sikap independensi dalam mengaudit.

Hasil penelitian sejalan dengan penelitian yang dilakukan (Yuniar, 2019) di kota Surabaya membuktikan bahwa indpendensi auditor mempunyai pengaruh yang positif terhadap kualitas audit. Hasil penelitian yang dilakukan oleh (Anggara \& Murti, 2019) Surakarta, yogyakarta dan Semarang juga membuktikan independensi berpengaruh positif terhadap kualitas audit. Juga sejalan dengan hasil penelitian Dewi \& Sudna (2018), Laksita dan Sukirno (2019) yang membuktikan bahwa pengalaman berpengaruh terhadap kualitas audit.

\section{c. Pengaruh Gender Auditor Terhadap Kualitas Audit pada KAP jakarta pusat}

Hipotesis ketiga, gender berpengaruh terhadap kualitas audit yang merupakan jawaban sementara untuk rumusan masalah nomor 3. Hasil uji t (parsial), diperoleh nilai signifikansi variabel gender sebesar 0,041<0,1 (taraf 
nyata signifikansi penelitian). Hasil perbandingan antara thitung dan ttabel yang menunjukan nilai thitung sebesar -2,002, sedangkan ttabel sebesar 1,667. Dari hasil tersebut terlihat bahwa thitung > ttabel yaitu $-2,002>$ 1,667. Hasil penelitian menunjukan bahwa variabel gender berpengaruh negatif terhadap kualitas audit,. maka dapat disimpulkan bahwa hipotesis ketiga diterima.

Besarnya pengaruh variabel gender terhadap kualitas audit secara parsial dapat dilihat dari hasil perhitungan determinasi parsial.Berdasarkan determinasi parsial besarnya pengaruh gender terhadap kualitas yaitu sebesar $4,3 \%$. Sehingga dapat dikatakan terdapat pengaruh gender terhadap kualitas audit namun pengaruhnya kecil.

Berdasarkan distribusi responden diketahui jenis kelamin responden dalam penelitian ini mayoritas laki-laki dengan persentase sebesar $67 \%$. Sisanya sebesar 33\% adalah Perempuan. Hasil penelitian menunjukan auditor wanita di KAP Jakarta pusat lebih baik dalam megaudit dibandingkan auditor laki-laki. Hasil penelitian ini sejalan dengan penelitian (Firman \& Rahayu, 2020) di KAP kota Bali gender berpengaruh negatif dan signifikan terhadap kualitas audit.

\section{d. Pengaruh Pengalaman, Independensi dan Gender terhadap kualitas Audit pada KAP Jakarta Pusat}

Hipotesis keempat pengalaman, Independensi, gender berpengaruh terhadap kualitas audit secara bersama-sama yang merupakan jawaban sementara untuk rumusan masalah nomor 5 terbukti dalam penelitian ini. Berdasarkan hasil pengujian hipotesis (uji F) didapat nilai signifikansi regresi secara simultan sebesar 0,043, nilai ini lebih kecil dari significance 0,1 (10\%), yaitu $0,043<0,1$. Selain itu dapat dilihat juga dari hasil perbandingan antara Fhitung dan Ftabel yang menunjukan nilai Fhitung sebesar 2,859 sedangkan Ftabel sebesar 2,166. Dari hasil tersebut terlihat bahwa Fhitung > Ftabel yaitu 2,859>2,166, maka dapat disimpulkan bahwa seacara bersama-sama atau secara simultan variabel Pengalaman, independensi dan gender secara signifikan berpengaruh terhadap variabel dependen yaitu variabel kualitas audit.Dengan demikian hipotesis keempat diterima.

Hasil penelitian ini sejalan dengan teori atribusi yang menggatakan bahwa perilaku seseorang juga dirinya ditentukan oleh kekuatan internal (internal forces) dan kekuatan eksternal (eksternal forces). Kualitas audit yang dihasilkan tergantung dari kekuatan yang dimiliki auditor itu sendiri. Kekuatan internal (pengalaman dan perbedaan gender auditor) maupun kekuatan eksternal (independensi).

Hasil penelitian ini diharapkan dapat memberi masukan bagi KAP untuk meningkatkan kualitas audit dan memberikan informasi mengenai faktor-faktor yang mempengaruhi kualitas audit beserta usaha-usaha yang dapat dilakukan 
untuk menjaga dan meningkatkan kualitas kerjanya sehingga dapat menghasilkan kualitas audit yang baik.

\section{Kesimpulan}

Berdasarkan penelitian diatas beberapa yang bisa disimpulkan: (1) Pengalaman auditor di KAP Jakarta Pusat termasuk kategori tinggi, karena mayorita responden menjawab tinggi. (2) Independensi auditor di KAP Jakarta Pusat termasuk kategori sangat tinggi, karena mayorita responden menjawab sangat tinggi. (3) Jenis kelamin yang berpartisipasi dalam penelitian ini didominasi oleh laki-laki. Jadi auditor di KAP Jakarta Pusat di dominasi oleh laki-laki. Namun hasil penelitian menunjukan auditor wanita lebih baik dalam mengaudit. (4) Kualitas auditor di KAP Jakarta Pusat termasuk kategori tinggi, karena mayoritas responden menjawab tinggi. (5) Tidak terdapat pengaruh pengalaman terhadap kualitas audit. (6) Terdapat Pengaruh independensi terhadap kualitas audit namun pengaruhnya kecil. (7) Terdapat pengaruh gender terhadap kualitas audit namun pengaruhnya kecil. (8) Terdapat pengaruh ketiga variabel independen yaitu pengalaman, independensi, gender terhadap variabel dependen yaitu kualitas audit, namun pengaruhnya kecil.

\section{BIBLIOGRAFI}

Agustina, Rina, Dartanto, Teguh, Sitompul, Ratna, Susiloretni, Kun A., Achadi, Endang L., Taher, Akmal, Wirawan, Fadila, Sungkar, Saleha, Sudarmono, Pratiwi, \& Shankar, Anuraj H. (2019). Universal health coverage in Indonesia: concept, progress, and challenges. The Lancet, 393(10166), 75-102.

Ambarwati, Novi Sagita, Yuniarta, Gede Adi, AK, S. E., \& SINARWATI, N. I. KADEK. (2015). Pengaruh modal kerja, likuiditas, aktivitas dan ukuran perusahaan terhadap profitabilitas pada perusahaan manufaktur yang terdaftar di bursa efek Indonesia. JIMAT (Jurnal Ilmiah Mahasiswa Akuntansi) Undiksha, $3(1)$.

Anggara, Ajiheri, \& Murti, Nugroho Wisnu. (2019). Effect Of Independence, Auditor Experience, Task Complexity, And Time Budget Pressure On Audit Quality (Study On Surakarta, Yogyakarta, And Semarang KAP). Journal of Indonesian Science Economic Research, 1(1), 7-12.

Ariningsih, Putu Setia, \& Mertha, I. Made. (2017). Pengaruh Independensi, Tekanan Anggaran Waktu, Risiko Audit, Dan Gender Pada Kualitas Audit. E-Jurnal Akuntansi, 18(2), 1545-1574.

Burhanudin, Muhammad Alifzuda, \& Rahmawati, Diana. (2017). Pengaruh Akuntabilitas dan Independensi Auditor Terhadap Kualitas Audit Pada Kantor Akuntan Publik di Yogyakarta. Jurnal Profita. 
Firman, Firman, \& Rahayu, Sari. (2020). Pembelajaran Online di Tengah Pandemi Covid-19. Indonesian Journal of Educational Science (IJES), 2(2), 81-89.

Gunur, Bedilius, Makur, Alberta Parinters, \& Ramda, Apolonia Hendrice. (2018). Hubungan antara kemampuan numerik dengan kemampuan pemecahan masalah matematis siswa di pedesaan. MaPan, 6(2), 148-160.

Huda, Nurul, Hudori, Khamim, Fahlevi, Rizal, Mazaya, Dea, \& Sugiarti, Dian. (2017). Pemasaran Syariah: Terori \& Aplikasi. Kencana.

Laksita, Arin Dea, \& Sukirno, Sukirno. (2019). Pengaruh Independensi, Akuntabilitas, Dan Objektivitas Terhadap Kualitas Audit. Nominal: Barometer Riset Akuntansi Dan Manajemen, 8(1), 31-46.

Momon, Momon, Rachbini, Widarto, \& Amilin, Amilin. (2018). Faktor Penentu Kualitas Audit Di Kantor Akuntan Publik Dki Jakarta. Jurnal Akuntansi, 7(2), 8599.

Mulyani, Susi Dwi, \& Munthe, Jimmi Osamara. (2018). Pengaruh Skeptisme Profesional, Pengalaman Kerja, Audit Fee dan Independensi terhadap Kualitas Audit pada KAP di DKI Jakarta. Jakarta: Univesitas Trisakti.

Nazir, Moh. (2011). Metode Penelitian, Cetakan Ke Tujuh. Bogor: Penerbit Ghalia Indonesia.

Oktaviani, Dahlia Sari. (2016). Diskriminasi Lgbt Di Media Massa (Analisis Wacana Kritis pada Pemberitaan LGBT di Koran Republika Edisi 15-21 Februari 2016). Universitas Bakrie.

Palupi, Ariani, Suratno, Suratno, \& Amilin, Amilin. (2018). Pengaruh Konvergensi Ifrs, Prediksi Kebangkrutan, Komite Audit, Komisaris Independen Dan Kualitas Audit Terhadap Timelines Perusahaan Tambang. JIAFE (Jurnal Ilmiah Akuntansi Fakultas Ekonomi), 3(1), 20-34.

Rahayu, Ni Kadek Sri, \& Suryanawa, I. Ketut. (2019). Pengaruh Independensi, Profesionalisme, Skeptisme Profesional, Etika Profesi dan Gender Terhadap Kualitas Audit Pada KAP di Bali. E-Jurnal Akuntansi, 30(3), 686-698.

Saputra, Bagus Rachmad, Adha, Maulana Amirul, Ariyanti, Nova Syafira, \& Gunawan, Imam. (2019). Tips for principal in managing one roof school (SATAP) in Underdeveloped Area. The 4th International Conference on Education and Management (COEMA 2019), 39-42. Atlantis Press.

Sarca, Delsi Nia, \& Rasmini, Ni Ketut. (2019). Pengaruh Pengalaman Auditor dan Independensi Pada Kualitas Audit Dengan Etika Auditor Sebagai Variabel Moderasi. E-Jurnal Akuntansi, 26(3), 2240-2267.

Segah, Boby. (2018). Pengaruh Pengalaman Kerja, Independensi, Objektivitas, dan 
Motivasi terhadap Kualitas Hasil Pemeriksaan Auditor Inspektorat Provinsi Kalimantan Tengah. Anterior Jurnal, 17(2), 86-99.

Septiana, Y., Munthe, A. R. S., Fatimah, D. D. S., \& Latifah, A. (2019). Prototype of decision support system for wind detection based on optocoupler and magnetic sensor. Journal of Physics: Conference Series, 1402(7), 77005. IOP Publishing.

Siahaan, Septony B., \& Simanjuntak, Arthur. (2019). Pengaruh Kompetensi Auditor, Independensi Auditor, Integritas Auditor Dan Profesionalisme Auditor Terhadap Kualitas Audit Dengan Etika Auditor Sebagai Variabel Moderasi (Studi Kasus Pada Kantor Akuntan Publik Di Kota Medan). Jurnal Manajemen, 5(1), 81-92.

Sihombing, Ade Andrianto. (2019). The Effect Of Independence, Objectivity, Competence And Work Experience On The Financial Investigation Quality Of Audit Firm In Indonesia. Jurnal Manajemen, Ekonomi, Bisnis Keuangan, 18(1).

Sihombing, Yohana Ariska, \& Triyanto, Dedik Nur. (2019). Pengaruh Inependensi, Objektivitas, Pengetahuan, Pengalaman Kerja, Integritas Terhadap Kualitas Audit (Studi Pada Inspektorat Provinsi Jawa Barat Tahun 2018).

Suharti, \& Apriyanti, Tri. (2019). The Effect Of Competence And Independence On The Quality Of Audits With Auditor's Ethics As A Moderation Variable. Jurnal Ilmiah Akuntansi, 3(2), 208-217.

Tandiontong, Mathius. (2013). Pengaruh Faktor Komitmen Profesi Akuntan, Komitmen Organisasi Kantor Akuntan Publik Dan Kepuasan Kerja Auditor Terhadap Implementasi Audit Independen Atas Laporan Keuangan Survei Terhadap Akuntan Yang Bekerja Sebagai Auditor Pada Kap Di Indonesia. Jurnal Ilmu Manajemen Dan Bisnis, 4(1).

Turgarini, Dewi. (2018). Gastronomi Sunda Sebagai Atraksi Wisata Di KOTA BANDUNG. Universitas Gadjah Mada.

Vangara, Shanmukha Varalakshmi, Kumar, Dhananjay, Gopichand, Patnaik V. V, \& Puri, Nidhi. (2019). Assessment Of Staheli Arch Index In Tribal Children Of Jharkhand State. Int J Anat Res, 7(1.2), 6161-6165.

Yuniar, L. and Sapari. (2019). Pengaruh Tekanan Waktu, Kompentensi, Independensi dan Etika Auditor Terhadap Kualitas Audit. Jurnal Ilmu Dan Riset Akuntansi, 8(5), 399-404. 